\title{
Involvement in Activities, Work Satisfaction and Retirement Expectations of Brazilian Federal Employees
}

\author{
PARTICIPACIÓN EN ACTIVIDADES, SATISFACCIÓN DE TRABAJO Y EXPECTATIVAS DE JUBILACIÓN DE \\ EMPLEADOS FEDERALES BRASILEÑOS
}

\begin{abstract}
Marina Gonçalves Martins', Ana Palmira Soares Santos², Fabio Scorsolini-Comin ${ }^{3}$, Fabiana Caetano Martins Silva e Dutra ${ }^{4}$
1. Center for Studies and Research in Work, Social Participation and Health (NETRAS), Uberaba, MG, Brazil.

2. Basic Education, Technical and Technological - CEFORES, Dean of Human Resources, Universidade Federal do Triângulo Mineiro, Uberaba, MG, Brazil.

3. Department of Psychology, Graduate Program in Psychology, Institute of Education, Literature, Arts, Humanities and Social Sciences, Universidade Federal do Triângulo Mineiro, Uberaba, MG, Brazil.

4. Department of Occupational Therapy, Graduate Program in Health Care, Researcher at Center of Studies and Researches on Work, Social Participation and Health (NETRAS), Universidade Federal do Triângulo Mineiro, Uberaba, MG, Brazil.
\end{abstract}

\section{RESUMEN}

La decisión de jubilarse es un evento importante en la vida de las personas y puede verse influido por varios factores, como los problemas de salud, la satisfacción laboral y el repertorio de actividades diarias. Objetivo: describir la participación en las actividades, evaluar la satisfacción laboral y comparar estas variables entre los trabajadores que están cerca de la jubilación. Métodos: se evaluaron 72 servidores de universidades públicas a través de datos sociales demográficos y ocupacionales; Sumario de diversidad en asignación de tiempo y cuestionario de satisfacción laboral. Resultados: la mayoría eran mujeres (59,7\%) con 56 años. Respecto a la decisión de retirarse, el 58.3\% no quiso retirarse. La satisfacción laboral mostró valores moderados a altos y no hubo diferencias entre los grupos. Los participantes presentaron una participación equilibrada en las actividades diarias, con una mayor asignación de tiempo para la atención personal y domiciliaria. El grupo que pretendía retirarse indicó pocas expectativas de cambios en sus actividades. Los trabajadores que pretenden posponer su jubilación están planeando transiciones en casi todas las áreas de actividades y relaciones. Conclusiones: la poca participación en las actividades y los trabajadores que desean jubilarse indicaron pocas expectativas de cambios en las actividades diarias. En contraste, los trabajadores que pretenden retrasar la jubilación tienen expectativas de cambios en la mayoría de las actividades.

(Gonçalves M, Soares A, Scorsolini F, Martins F, 2018. Participación en Actividades, Satisfacción de Trabajo y Expectativas de Jubilación de Empleados Federales Brasileños. Cienc Trab. Sep-Dic; 20 [63]: 131-136).

Palabras clave: JUBILACIÓN; SATISFACCIÓN LABORAL; ACTIVIDADES DIARIAS, SECTOR PÚBLICO.

\section{ABSTRACT}

The decision for retirement is an important event in the life of people and may be influenced by several factors such as health problems, work satisfaction and repertoire of daily activities. Aim: to describe the involvement in activities, to assess work satisfaction and to compare these variables between workers who are close to retirement. Methods: 72 servers of public university were evaluated through a demographic and occupational social data; Diversity Sum in Time Allocation and Work Satisfaction Questionnaire. Results: Most were women (59.7\%) with an 56 years old. Regarding the decision of retiring, 58.3\% did not want to retire. The work satisfaction showed moderate to high values and there was no difference between the groups. Participants presented a balanced involvement in daily activities, with greater allocation of time to personal and home care. The group intending to retire indicated little expectation of changes in their activities. Workers who intend to postpone their retirement are planning transitions in almost all areas of activities and relationships. Conclusions: Poor involvement in activities and workers who want to retire indicated few expectations of changes in daily activities. In contrast, workers who intend to delay retirement have expectations of changes in most of the activities.

Key words: RETIREMENT; WORK SATISFACTION; DAILY ACTIVITIES, PUBLIC SECTOR.

\section{INTRODUCTION}

In recent years, the aging of the working population has become a frequent theme in population studies. Population aging has been

Correspondencia / Correspondence:

Sra. Fabiana Caetano Martins Silva e Dutra.

NETRAS - Center for Studies and Research in Work, Social Participation

and Health, Universidade Federal do Triângulo Mineiro.

Getúlio Guaritá Avenue, number 159, romm 329, $3^{\circ}$ floor,

Centro Educacional. CEP 38025-440, Uberaba, MG, Brazil.

Tel.: +55 3430761258

e-mail: fabiana.dutra@uftm.edu.br

Recibido: 01 Marzo de 2018 / Aceptado: 25 de Agosto de 2018 perceived in the labor market since there has been a greater number of older workers participating in the occupational and economic dynamics in Brazil. ${ }^{1}$ It is expected that at least $13 \%$ of the economically active Brazilian people will be 60 -year-old or older. ${ }^{2}$

The experience and knowledge accumulated over the years of work, as well as the meaning work has to one's adult life $\mathrm{e}^{3,4}$, are important factors that influence most of the workers to continue working even after they reach the age to retire. On the other hand, there are workers who want and wait for retirement motivated by the prospect of spending more time with their family, and to devote themselves to leisure or even to the completion of old projects. Retirement is a time of greater freedom and professional disengagement, bringing new opportunities and achievements. ${ }^{5,6}$ But for some workers, the retirement process can be experienced as a break imposed by the external world, generating frustrations. ${ }^{7}$ 
Thus, retirement is an important event for people and may cause positive or negative impacts. The time of retirement can be an opportunity to build new projects with more free time, contributing to give more positive meanings to one's life. ${ }^{6,8}$ However, when assimilated in a negative way, it can bring problems to the psychic structure of the individual; it can be a time of loss of labor activities, of identity and social relationships. ${ }^{7,9}$ Previous studies indicate a number of factors that workers consider before making a final decision on retirement. ${ }^{6,10-13}$ Some researchers suggest health problems as the most important reason for an early retirement. ${ }^{10,11}$ Other researchers suggest a variety of factors, such as low work satisfaction, lack of social support and poor repertoire of daily activities. ${ }^{6,12-14}$

In this context, the retirement process is not only a temporary situation, but a whole set of psychological, social, physical and functional factors that happen in a certain moment of one's life cycle, and that demands a multivariate analysis of events. Special attention is needed with workers involved in fewer activities, with difficulties to identify new habits and difficulties to plan their daily life and their future. Aware of these issues, several studies have been analyzing the work conditions and the setting up for retirement of workers going through their aging process ${ }^{6,9,12-14}$, together with the frequent public teaching institution programs that offer preparation for retirement, and aim at offering psychosocial support for this people. Considering this background, the objective of this study was to analyze the connections among the involvement with different day to day activities, work satisfaction and expectations regarding retirement among workers in a Brazilian public university.

\section{METHODS}

Quantitative study, with a cross-sectional observational design, conducted with public servers of the Federal University of Triângulo Mineiro (UFTM), in the southeast region of Brazil. For convenience, permanent servers (permanent professors and technical-administration workers) were selected, but only those who had been working for at least a year in the institution, and who can retire within three years, that is, professionals who are already preparing for their retirement. Workers on leave of absence were excluded, together with those who would take longer than three years to be retired. All participants signed the Informed Consent, which was approved by the Committee of Ethics in Research of UFTM (Protocol no. 788.600).

\section{Instrumentation and Procedures}

Socio-demographic and occupational characteristics were registered in a questionnaire which identified: gender, age, marital status, education, number of children, time worked in the institution, time left before retirement, sector, work performed, income, and working hours. The decision/expectation to retire was evaluated through the use of two open questions: (1) if there was still some time left before their retirement, the workers were asked: "Considering that you are still a few years to be retired, what decision have you made or intend to make regarding your work?"; or (2) in case the worker had already completed the required time to retire, he was asked: "Considering that you could already be retired , what decision did you take or will take regarding your work today?". The answers to both questions were categorized and the participants were separated in two groups: one consisting of workers who want to retire, and the other consisting of those who want to keep working.
In order to measure the involvement of the participants in activities, the instrument "Diversity in the Activities in Time Allocation (SOD)", elaborated by França et $\mathrm{al}^{15}$, was used. This instrument calculates the diversity of the involvement in activities during one's working life, and the expectation of future involvement after retirement. The instrument comprises 45 activities, which were separated in nine categories: (1) work; (2) investments; (3) education; (4) politics and community; (5) activities related to home and family life; (6) culture and leisure; (7) spirituality; (8) personal care and health; and (9) social, family and emotional life. ${ }^{15}$

Work satisfaction was evaluated through the use of the Questionnaire of Work Satisfaction S20/23, whose use was validated and adapted to the Brazilian reality by Carlotto and Câmara. ${ }^{16}$ This instrument consists of three dimensions: Hierarchical Relations Satisfaction - HRS; Work Physical Environment Satisfaction - WPES; and Intrinsic Work Satisfaction and Growth Opportunity Satisfaction - IWSGW - to a total of 20 items, measured with a Likert five-point scale, going from "completely unsatisfied" to "completely satisfied". The total score of the questionnaire is estimated by averaging the scores obtained in each dimension, considering the grater the score, the greater the satisfaction. ${ }^{16}$

\section{Data Analysis}

Data were submitted to descriptive analysis and normality test. To compare the involvement in activities and work satisfaction between the two groups of workers, the Mann-Whitney U test was used. To compare the current involvement in activities and the prediction the specific future involvement of each group, the Wilcoxon Test was used. The adopted significance level was 5\% and analyzes were performed using the SPSS IBM ${ }^{\circledR}$, version 20.0.

\section{RESULTS}

Sample consisting of 72 workers interviewed between December 2014 and February 2015. Most were women (59.7\%), with an age average of 56 years old ( $\mathrm{SD}=4.42$ ), ranging from 48 to 69 years old. Regarding their marital status, 48 (66.7\%) were married, with an average of two children $(\mathrm{SD}=1.98)$, and 11 workers reported not having children. The maximum was six children of the same worker. More than half were graduated (52.8\%) and had worked at the institution for about two years $(\mathrm{SD}=7.13)$.

Among participants who had not yet completed their retirement time, the remaining time to retire ranged from one to three years, with an average of 18 months $(\mathrm{SD}=10.07)$. Among the workers who were already allowed to retire, the amount of time after their retirement along which they continued working varied between one and 11 years old (average $=3$ years; $S D=27.89$ ). Most were technical-administrative personnel (88.9\%) and worked eight hours a day with an average salary of \$ 1,685.36 a month $(\mathrm{SD}=914.72)$.

Regarding their decision for retirement, 42 (58.3\%) workers did not want to retire, while $30(41.7 \%)$ wanted to retire. Both groups of workers presented similar socio-demographic and occupational characteristics for almost all variables, suggesting homogeneity. Regarding education, the group of workers who wanted to retire had more years of education than participants who wanted to remain in work activities. Tables 1 and 2 show the demographic and occupational data of the participants. 
Table 1.

Description of quantitative demographic and labor data of workers interviewed $(n=72)$. Uberaba-MG, 2017.

\begin{tabular}{lcccccc} 
Variables & \multicolumn{2}{c}{ ALL WORKERS } & \multicolumn{2}{c}{ WORKERS WHO WANT TO RETIRE } & \multicolumn{2}{c}{ WORKERS WHO WANT TO KEEP WORKING } \\
Amplitude & Average (SD) & Amplitude & Average (SD) & $\begin{array}{c}\text { Amplitude } \\
\text { Average (SD) }\end{array}$ \\
Age & $48.00-69.00$ & $55.95(4.42)$ & $50.00-69.00$ & $56.40(4.62)$ & $48.00-65.00$ & $55.64(4.31)$ \\
Number of children & $0.00-6.00$ & $1.98(1.25)$ & $0.00-4.00$ & $1.73(1.20)$ & $0.00-6.00$ & $2.16(1.26)$ \\
Time working at UFTM & $5.00-40.00$ & $27.00(7.13)$ & $5.00-35.00$ & $25.26(7.15)$ & $5.00-40.00$ & $28.23(6.93)$ \\
Time remaining to retire & $1.00-36.00$ & $19.62(10.07)$ & $1.00-36.00$ & $21.77(10.94)$ & $1.00-36.00$ & $18.29(9.53)$ \\
Time since participant & $1.00-132.00$ & $33.23(27.89)$ & $1.00-60.00$ & $21.64(17.70)$ & $1.00-132.00$ & $42.61(31.33)$ \\
could have already retired & $724.00-14,000.00$ & $4,837.00(2,625.25)$ & $724.00-14,000.00$ & $5,420.13(3,249.08)$ & $1,200.00-11,000.00$ & $4,420.47(2,010.35)$
\end{tabular}

Table 2.

Description of the categorical demographic and labor data of the workers interviewed. ( $N=72)$. Uberaba-MG, 2017.

\begin{tabular}{|c|c|c|c|c|c|c|}
\hline \multirow[b]{2}{*}{ Variables } & \multicolumn{2}{|c|}{ ALL WORKERS } & \multicolumn{2}{|c|}{ WORKERS WHO WANT TO RETIRE } & \multicolumn{2}{|c|}{ WORKERS WHO WANT TO KEEP WORKING } \\
\hline & Frequency & Percentage (\%) & Frequency & Percentage (\%) & Frequency & Percentage $(\%)$ \\
\hline \multicolumn{7}{|l|}{ Gender } \\
\hline Male & 29 & 40.3 & 12 & 40.0 & 17 & 40.5 \\
\hline Female & 43 & 59.7 & 18 & 60.0 & 25 & 59.5 \\
\hline \multicolumn{7}{|l|}{ Marital status } \\
\hline Single (a) & 7 & 9.7 & 4 & 13.3 & 3 & 7.1 \\
\hline Married or lives with partner & 48 & 66.7 & 17 & 56.7 & 31 & 73.8 \\
\hline Separated or divorced & 13 & 18.1 & 7 & 23.3 & 6 & 14.3 \\
\hline Widower & 4 & 5.6 & 2 & 6.7 & 2 & 4.8 \\
\hline \multicolumn{7}{|l|}{ Education } \\
\hline Incomplete primary education & 6 & 8.3 & 1 & 3.3 & 1 & 2.4 \\
\hline Complete primary education & 2 & 2.8 & 2 & 6.7 & 4 & 9.5 \\
\hline Incomplete high school & 10 & 13.9 & 1 & 3.3 & 3 & 7.1 \\
\hline Complete high school & 4 & 5.6 & 2 & 6.7 & 8 & 19.0 \\
\hline Incomplete higher education & 6 & 8.3 & 3 & 10.0 & 3 & 7.1 \\
\hline Complete higher education & 6 & 8.3 & 1 & 3.3 & 5 & 11.9 \\
\hline Postgraduate studies & 38 & 52.8 & 20 & 66.7 & 18 & 42.9 \\
\hline \multicolumn{7}{|l|}{ Position } \\
\hline Technical-Administrative & 64 & 88.9 & 29 & 96.7 & 35 & 83.3 \\
\hline Professor & 8 & 11.1 & 1 & 3.3 & 7 & 16.7 \\
\hline \multicolumn{7}{|l|}{ Decision regarding retirement } \\
\hline Wants to retire & 30 & 41.7 & & & & \\
\hline Does not want to retire & 42 & 58.3 & & & & \\
\hline
\end{tabular}

Current involvement in activities and prediction of involvement in activities after retirement

As for the current involvement in different activities, we observed a higher allocation of time for home caring activities, domestic life, personal care and spirituality. Involvement in culture and leisure activities, social and family life, politics and investments was moderate. Educational and work activities showed less involvement, i.e., the workers allocated less time for them. Regarding time allocation prediction during retirement, all participants intend to significantly reduce work activities $(\mathrm{p}=0.000)$ and increase activities related to education $(p=0.001)$, recreation and culture $(p=0.000)$, spirituality $(p=0.008)$, personal care $(p=0.013)$ and social and family life $(p=0.000)$. Table 3 presents the description of current involvement in activities and expectations of involvement after retirement.

\section{Involvement in Activities and Prediction of Involvement in Activities after Retirement among Workers Who Want to Retire}

The analysis of the involvement in activities for the group of workers who want to retire presented a statistically significant
Table 3.

Ongoing activities and prediction to start developing them in retirement ( $n=72$ ). Uberaba-MG, 2017.

$\begin{array}{lccc}\text { Activities } & \begin{array}{c}\text { Current } \\ \text { Average (SD) }\end{array} & \begin{array}{c}\text { In retirement } \\ \text { Average (SD) }\end{array} & \begin{array}{c}\text { P value } \\ \text { Work }\end{array} \\ \text { Investment } & 56.80(10.81) & 40.43(13.38) & 0.000^{*} \\ \text { Education } & 39.07(25.55) & 60.41(24.63) & 0.140 \\ \text { Politics and community } & 58.24(21.02) & 47.31(25.44) & 0.001^{*} \\ \text { Related to home and family life } & 83.70(15.21) & 84.53(18.62) & 0.342 \\ \text { Culture and leisure } & 69.32(12.74) & 76.63(12.12) & 0.214 \\ \text { Spirituality } & 76.66(25.78) & 80.00(24.43) & 0.000^{*} \\ \text { Personal and health care } & 81.75(16.82) & 83.70(16.01) & 0.008^{*} \\ \text { Social, family and emotional life } & 67.75(10.69) & 71.16(10.94) & 0.003^{*}\end{array}$

${ }^{*} \mathrm{P}<0.05$ is significant for the Wilcoxon Signed Rank test.

difference in the categories work, education, culture and social and family life when the current allocation of time was compared to the prediction of time allocation. This result indicates that, after retirement, this group of workers aims to reduce the involvement 
Table 4.

Involvement in activities, comparing the current time allocation and the time allocation predictions for each worker group separately (workers who want to retire and workers who do not want to retire), ( $n=72)$. Uberaba-MG, 2017.

\begin{tabular}{|c|c|c|c|c|c|c|}
\hline Activities & $\begin{array}{c}\text { WORKERS W } \\
\text { Current } \\
\text { Average (SD) }\end{array}$ & $\begin{array}{l}\text { NT TO RETIRE } \\
\text { In retirement } \\
\text { Average (SD) }\end{array}$ & $P$ value & $\begin{array}{c}\text { WORKERS WHC } \\
\text { Current } \\
\text { Average (SD) }\end{array}$ & $\begin{array}{l}\text { KEEP WORKIN } \\
\text { In retirement } \\
\text { Average (SD) }\end{array}$ & $P$ value \\
\hline Work & $18.06(4.29)$ & $14.9(4.73)$ & $0.000^{*}$ & $16.38(3.24)$ & $13.61(4.62)$ & $0.000^{*}$ \\
\hline Investment & $5.93(2.71)$ & $6.66(2.38)$ & 0.267 & $5.50(2.45)$ & $5.59(2.45)$ & 0.671 \\
\hline Education & $5.36(3.73)$ & $6.83(3.57)$ & $0.002^{*}$ & $6.21(3.63)$ & $7.28(4.01)$ & $0.043^{*}$ \\
\hline Politics and community & $8.90(3.25)$ & $9.16(2.56)$ & 0.279 & $8.61(3.11)$ & $8.09(2.89)$ & $0.041^{*}$ \\
\hline Related to home and family life & $12.86(2.50)$ & $13.06(2.21)$ & 0.388 & $12.33(2.11)$ & $12.40(2.15)$ & 0.496 \\
\hline Culture and leisure & $31.36(6.38)$ & $34.93(5.71)$ & $0.000^{*}$ & $31.07(5.30)$ & $34.16(5.30)$ & $0.000^{*}$ \\
\hline Spirituality & $3.80(1.54)$ & $3.93(1.43)$ & 0.279 & $3.85(1.09)$ & $4.04(1.05)$ & $0.005^{*}$ \\
\hline Personal and health care & $12.83(2.46)$ & $13.00(2.33)$ & 0.429 & $11.85(2.51)$ & $12.23(2.42)$ & $0.038^{*}$ \\
\hline Social, family and emotional life & $34.13(5.92)$ & $36.60(6.22)$ & $0.000^{*}$ & $33.69(4.96)$ & $34.85(4.81)$ & $0.001^{*}$ \\
\hline
\end{tabular}

${ }^{*} p<0,05$ is significant for the Wilcoxon Signed Rank test.

in work activities $(p=0.000)$ and increase the allocation of time to educational activities $(\mathrm{p}=0.002)$, cultural and leisure activities $(\mathrm{p}=0.000)$ and social and family life $(\mathrm{p}=0.000)$.

\section{Involvement in Activities and Prediction of Involvement after Retirement among Workers Who Want to Remain Working}

In the group of workers who want to keep working, there was a significant difference in the current and future time allocations for a greater number of activities. These participants expect to reduce involvement in work and politics/community activities ( $p=0.000$ and $p=0.041$, respectively); and to increase involvement in education ( $p=0.043)$, leisure and culture $(\mathrm{p}=0.000)$, family and social life $(p=0.001)$, personal care $(p=0.038)$ and spiritual $(\mathrm{p}=0.005)$ activities.

Comparing the current allocation of time in the different categories of activities and the prediction of time allocation after retirement, the two groups of workers do not show statistical differences between them. Table 4 shows comparison between the two groups of workers, considering their involvement in current activities and their prediction of time allocation after retirement

\section{Comparison of Work Satisfaction among Groups of Workers}

The workers showed high satisfaction values at work in IWSGW and HRS dimensions (average $=82.63 ; \mathrm{SD}=12.16$; and average $=80.45 ; \mathrm{SD}=10.74$ respectively). The WPES dimension, which regards the work physical environment, had lower satisfaction score according to the interviewed workers (average $=70.33$; $\mathrm{SD}=20.67$ ). The analysis of work satisfaction separated by group of workers showed the same pattern, with no statistical difference, as described in Table 5.

\section{Table 5.}

Work satisfaction comparison between the group of workers who wants to retire and workers who does not. ( $\mathrm{N}=72)$. Uberaba-MG, 2017.

\begin{tabular}{llcc}
\multicolumn{3}{c}{$\begin{array}{c}\text { Workers who want to retire } \\
\text { Average (SD) }\end{array}$} & $\begin{array}{c}\text { Workers who want to keep working } \\
\text { Average (SD) }\end{array}$ \\
WS & $82.00(13.16)$ & $83.09(11.52)$ & 0.839 \\
WPES & $74.93(17.51)$ & $67.04(22.29)$ & 0.149 \\
HRS & $80.66(11.63)$ & $80.30(10.19)$ & 0.548
\end{tabular}

$p<0.05$ is significant for Mann-Whitney $U$ test.

\section{DISCUSSION}

This study aimed at evaluating the involvement in different activities and work satisfaction of federal employees who are close to retirement. The results point to a female sample composed mostly of administrative staff. The data collection period occurred during the academic holidays (December to February), which may explain the low percentage of professors in the sample. Commonly, this is the preferred period for professors to enjoy their holidays, in order to facilitate the professional performance and fulfillment of academic activities throughout the school year. This practice is not common among the administrative staff, who have work activities less dependent on institutional and academic calendars. Other studies also point to the increased presence of women in the list of workers in Brazilian public universities, associating this phenomenon to eminently feminine roles such as caring and teaching. ${ }^{17}$ The intensity and steady increase of female participation in the labor market, which has been taking place since the mid-1970s on a national level ${ }^{17}$ also needs to be highlighted.

The evaluated participants present high level of education - a high percentage of workers enjoy graduate degrees. This is a common framework in Brazilian public universities, in which the hiring of professors with $\mathrm{PhD}$. and master's titles needs to be followed by the hiring of appropriate technical and administrative staff. Another factor that stimulates the high level of education is the association of such level with career progression and its impact on the salary of the technical and administrative staff. ${ }^{18}$

In 2005, with the implementation of the Plan for Restructuring and Expansion of Federal Brazilian Universities (REUNI), the Federal University of Triângulo Mineiro has undergone significant growth and an exponential increase in its staff. Thus, although the respondents are close to retirement, or are already allowed to retire, most workers have only recently started working in the institution, what justifies the low average working time (2 years). Regarding monthly income, participants have gains compatible with the remuneration of federal public workers in Brazil. ${ }^{19}$

When it comes to the decision for retirement, more than half of the workers want to keep their work activities (58.3\%). In a study conducted in 2012 with 148 federal public workers in Rio de Janeiro, 32\% did not intend to retire. $^{20}$ In another study 
conducted in Viçosa-MG, more than half of the federal public workers surveyed wanted to continue working. ${ }^{21}$ These investigations point to a large number of workers who, despite being close to retirement, or even being already able to retire, prefer to keep their working activities. This result, coupled with the aging of the population, reinforces the increased participation of older workers in the occupational and economic dynamics in Brazil. Regarding the decision to continue working or to definitively retire, biopsychosocial and work factors are extremely important in this process. Age, sex, health status, socio-economic status and work characteristics could retain older workers longer in the labor market. ${ }^{6}$ Jebens et $\mathrm{al}^{22}$ associates an interesting work as an important factor to remain working. Thus, workers with better psychosocial working conditions and greater work satisfaction, as observed in our results, are more likely to continue working even after retirement age.

The decision to retire also involves social aspects such as prejudice, discrimination and social representations regarding the aging process and the need to remain active. ${ }^{6}$ In Brazil, there is still a strong association between retirement and old age. Despite approaching their retirement age, the workers of this study can be considered young (average age of 56 years old) and the decision for retirement could socially represent an early entry in old age. In this sense, keeping work activities can also suggest an attempt by workers to delay the aging process and its repercussions, which are usually considered to be negative.

The evaluated workers presented a moderate involvement in cultural, leisure and social and family life activities. In addition, time allocation was not very diversified, as it was focused more on domestic activities such as home care, personal care and religious activities. These results may also explain the percentage of workers who wish to keep working. In the absence of cultural, leisure and social and family life activities, work is important for the conservation of social roles and individual's identity, besides contributing to the establishment of social relations networks and emotional exchanges.

The work importance and the possibility of social losses are described in the literature as variables related to the preference for late retirement. ${ }^{6}$ So, what to do in this new stage of life after retirement and without work, and how to use and manage the available time are challenges for people who experience the retirement process. Leisure, cultural and recreational activities are considered actions performed without the obligation to be productive, they offer relaxation and personal growth, allow greater sense of personal value, greater socialization and adjustments in the organization of life. ${ }^{23,24}$

On the other hand, the post-retirement time is an opportunity for a worker to experience new situations, develop skills, abilities, to discover new interests, and resume interrupted projects, offering social expectations, organizing the use of time and inserting the individual in a social structure which is different from the workplace. Since all surveyed participants intend to increase their involvement in cultural, leisure, social and family life, this can be an environment which enables the workes to allocate their time better, including their involvement in intellectual, voluntary, cultural and leisure activities, for example.

Work and educational activities had the lowest time allocation scores. This result suggests that participant's work load is not excessive and excludes the possibility of intensifying their work. On the other hand, this result also indicates little involvement of workers in what are considered to be growth activities, such as volunteer work or courses attendance. Pereira et $\mathrm{al}^{25}$ highlight the importance of maintaining this balance between work activities and personal life. Seabra and Dutra ${ }^{26}$ also highlight the importance of maintaining a balance between work activities and participation in recreational and leisure activities that promote well-being and health. This balance provides the employee with a greater flexibility of time, what is fundamental in retirement, when people have more "available" time.

The diversity of activities (SOD) was more successful at discriminating the two groups when analyzing the future expectation of time allocation. The average SOD did not show any difference between the analyzed groups, and both intend to reduce the allocation of time at work and to increase involvement in activities in the areas of education, culture and social life. However, workers who intend to postpone retirement are more likely to reduce the allocation of time in activities related to politics, and to devote more time to personal care and religious activities. To França et $\mathrm{al}^{13}$, engaging in religious and self-centered activities is a characteristic of Brazilian people, given the broad religious and spiritual repertoire which pervades the population. However, the expectation to devote more time to educational activities may be a possibility to live new experiences that people have always wanted in the past and did not have enough time to. ${ }^{27}$ Education can also help in the development of new interests and perspectives and provide spaces for the expansion of social support networks, offering people who are retiring a key point in the reconstruction of their life stories.

Regarding work satisfaction, the results are positive and indicate that respondents are satisfied when it comes to the three analyzed areas. The dimension related to the work physical environment presented the lowest satisfaction score among workers. It is important to note that, currently, the university is in a context of growth and expansion, with buildings being constructed, reconstructed and renovated, and various sectors are working in temporary structures until the completion of the works. Such temporary structures do not always meet the ideal requirements for ventilation, air conditioning, lighting and housing adequacy, which can lead to situations of dissatisfaction and stress. However, it is expected that this situation can be positively changed with the opening of new university facilities.

This study focused on the engagement in activities and on work satisfaction by means of a cross-sectional analysis and a multivariate methodological approach. The decision for retirement was dichotomized into "yes" and "no". In order to advance in the research regarding this issue, we can suggest investigations that consider a more flexible/extended categorization, taking into account options such as half-time work, voluntary work or the existence of personal projects. Other forms of categorization can also be recommended, such as the complete lack of decisions regarding work, the intention to retire on a previously scheduled date and the expectation of mandatory retirement. In this study, the sample has similar characteristics to that of administrative technical workers in Brazilian public universities, and generalizations regarding the professors should be made with reservations. The results become important as they explore the involvement in activities during the retirement process of a specific professional category. Literature on retirement in Brazil presents many challenges to be overcome, especially when considering the distribution of daily activities and its impact on the retirement process. 


\section{CONCLUSION}

Work satisfaction presented moderate to high values and there was no difference between the group of workers who want to retire and those who intend to delay retirement. Employee involvement in cultural, leisure and social and family life activities was moderate and the allocation of time was not very diversified. It was more focused on domestic activities such as home care, personal care and religious activities. Participants who wish to retire indicated few expectations of changes in the various categories of activities. On the other hand, workers who intend to postpone retirement, envision this stage of life with changes in most of the analyzed categories of activities.

Considering the projected life expectancy and the aging of the working population, the creation of programs designed for people who wish to continue working is suggested, in order to keep them satisfied in their work activities. As for those who wish to retire, the results provide basic subsidies for the (re)structuring of programs which prepare for retirement. They can be developed from data such as the highlighted in this study, and may contribute to the adoption of strategies more suitable to the expectations and needs of that particular audience.

\section{REFERÊNCIAS}

1. Nalin CP, França LHFP. The importance of resilience for well-being in retirement. Paidéia. 2015; 25(61):191-199.

2. Vanzella $E$, Lima Neto EA, Silva CC. The third age and the labour market. Rev bras cienc saúde. 2011; 14(4):97-100.

3. Ghirardi MIG, Lancman S. Thinking about new practices in Occupational Therapy. Rev Ter Ocup Univ São Paulo. 2002; 13(2):44-50.

4. Murta SG, Abreu S, França CL, Pedralho M, Seidl J, Lira NPM, Carvalhedo RKM, Conceição AC, Gunther IA. Preparing for retirement: implementation and evaluation of Live More Program. Psicol Reflex Crit. 2014; 27(1):1-9.

5. Alvarado I, Huerta APL, Díaz CAO, González VAV, Waleska K. Jubilación: Cambios en relación percibidos the routines y roles en mayores adults in institutionalized de la ciudad de Punta Arenas. Rev chil ter ocup. 2012; 12(1):60-71.

6. Bendassolli PF, França LH, Macedo SS, Menezes GS. Retire or Continue Working? What influences this decision? Psicol cienc profes. 2013; 33(3):548-563.

7. Lytle MC, Clancy ME, Foley PF, Cotter EW. Current trends in retirement implications for career counseling and vocational psychology. J Career Dev. 2015; 42(3):170-184.

8. Jonsson H. The First Steps into the Third Age: The Retirement Process from a Swedish Perspective. Occup Ther Int. 2011; 18(1):32-38.

9. Carmona CF, Couto WD, Scorsolini-Comin F. The experience of loneliness and the social support to elderly women. Psicol estud. 2014; 19(4):681-691.

10. Van den Berg TIJ, Elders LAM, Burdorf A. Influence of Health and Work on early retirement. J Occup Environ Med. 2010; 52(6): 576-583.

11. Nilsson $K$, Hydbom AR, Rylander L. Factors influencing the decision to extend working life or to retire. Scand J work env hea. 2010; 37(6):473-480.

12. Zanelli JC. Psychosocial processes, well-being and stress in retirement. Rev Psicol, Organ Trab. 2012; 12(3):329-340.

13. França $\mathrm{CL}$, Murta SG, Negreiros JL, Pedralho M, Carvalhedo R. Brief intervention in preparation for retirement. Rev bras orientac prof. 2013; 14(1):99-110.

14. França LHFP, Soares DHP. Preparation for retirement as part of education throughout life. Psicol Cienc Profes. 2009; 29(4):738-751.
15. França, LH, Nalin, C P, Siqueira-Brito AR, Amorim SM, Rangel T, Ekman NC A percepção dos gestores brasileiros sobre os programas de preparação para a aposentadoria. Estud Interdiscipl Envelhec. 2014; 19(3):879-898.

16. Carlotto MS, Câmara SG. Psychometric satisfaction questionnaire at work properties (S20/23). Psico-USF. 2008; 13(2):203-210.

17. Bruschini MCA. Labor and gender in Brazil in the last ten years. Cad Pesq. 2007; 37(132):537-572.

18. Cerqueira L, lliescu D, Martins JL, Nascimento HM, Neder MLC, Rodrigues YP, Silva AS, Silva TN, Weska AR. Analysis on the Expansion of Federal Universities 2003 to 2012. Report by Order no 126/2012. Brasilia: MEC; 2012.

19. Brazil. Ministry of Planning, Budget and Management (BRASIL/MPOG). Compensation Table of the Public Federal Civil Servants and former territories. 64. Brasilia: Ministry of Planning, Budget and Management; 2014.

20. França $L H$, Menezes GS. Retirement decision predictors of federal public servants. Rev Psicol Organ Trab. 2012; 12(3):315-328.

21. Bressan MA, Mafra SC, França HF, Melo MS, Loretto MD. Retirement wellbeing: what does this mean to federal civil servants? Rev bras geriatr gerontol. 2013; 16(2): 259-272.

22. Jebens E, Medbøa Jl, Knutsen O, Mamen A, Veiersted KB. Association between perceived present working conditions and demands versus attitude to early retirement among construction workers. Work. 2014; 48 (2):217-228.

23. Knox SH. Treatment through play and leisure. In: Neistadt M, Blesedell $E_{\text {, }}$ editores. Willard \& Spackman Occupational therapy. 9a ed. Philadelphia: Lipincott; 1998. p.382-390

24. Glantz CH, Richman N. Leisure activities. In: Pedretti LW, Early MB. Occupational Therapy: practical skills for physical dysfunctions. 5a ed. São Paulo: Roca; 2005. p. 268-275.

25. Pereira AAS, Couto WD, Scorsolini-Comin F. Motivations of elderly to participate in the Open University Program for Senior Citizens. Rev bras orientac prof. 2015; 16(2):207-217.

26. Seabra MMA, Silva-Dutra FCM. Intensification of Labor and Health Perception in teachers of a Brazilian Public University. Cienc Trab. 2015; 17(54):198-204.

27. Antunes MH, Moré CL. Family, work and retirement: a review of scientific literature on the Brazilian scene. Contexto clin. 2014; 7(2):145-154. 